ISSN:

Print - $2277-0755$

Online - $2315-7453$

(c) FUNAAB 2015

\title{
PHYSIOLOGICAL AND YIELD RESPONSE OF SOME UPLAND RICE VARIETIES TO RE-WATERING AFTER IMPOSED SOIL MOISTURE STRESS
}

\author{
*0.S. SAKARIYAWO ${ }^{1,}$ S.0. O LAGUNJU1, M.O. ATAYESE 1 , K.A. OKE LEYE1, \\ P.A.S., SO REMI'1, S.G. ADERIBIGBE, C.J. O KONJI'2, A.A. OYEKANMI ${ }^{1}$.
}

1 D epartment of Plant Physiology and Crop Production, Federal University of Agriculture, Abeokuta, P.M.B. 2240, Alabata, O gun State, Nigeria.

2 D epartment of Crop Science and Horticulture, Faculty of Agriculture, Federal University Oye-Ekiti, P.M.B. 373, Ekiti State, Nigeria

*Corresponding author: adetanwa@yahoo.co.uk

\begin{abstract}
.A pot experiment was conducted in the Screen house of Federal University of Agriculture, Abeokuta, October, 2011 (late dry season) to study drought recovery ability of 13 upland rice varieties exposed to soil moisture stress (20 days) at three growth stages (vegetative, reproductive and grain filling stage). The experiment was in completely randomized design, with three replicates. Under moisture stress significantly higher growth recovery, more erect canopy and flatter leaf surface were obtained in all the rice varieties at vegetative growth stage than other growth stages with increasing duration of rewatering. Under stress condition NERICA 4 maintained a significantly higher leaf area $\left(27.50 \mathrm{~cm}^{2}\right.$ and $\left.40.18 \mathrm{~cm}^{2}\right)$, plant height $(53.45 \mathrm{~cm}$ and $67.62 \mathrm{~cm}$ ) and number of tillers (1.67 and 1.67), but with a depressed number of leaf, slanted leaf posture and curved leaf especially during the later stage of its growth (Reproductive and grain filling stage respectively). It could be concluded that NERICA 4 had higher recovery ability than other rice varieties in drought prone upland ecology.
\end{abstract}

Keywords: Rice, Growth recovery, foliar character, re-watering, growth stage, NERICA

\section{INTRODUCTION}

D rought is a common environmental phenomenon in most parts of the world (Reddy e al., 2004). It is a production constraint that is accompanied with high temperature and moisture stress. Soil moisture stress alone could limit crop performance owing to the fact that most physiological and biochemical processes that support crop yield could only take place in the presence of water as a substrate. The severity of this phenomenon is compounded by the changes in global climate (Cheves \& al., 2003). Tropical regions of the world are characterized by erratic pattern of rainfall, mostly the rainforest transitory zone of Nigeria.

Rice is a staple food for most people in the developing countries. Its production, constrained by moisture stress in upland ecology could grossly compromise food security and its concomitant socio-economic effects. Rice is highly susceptible to soil moisture stress due to the peculiarity of its leaf morphological characteristics; low epicuticular surface (Austin, 1989), with increasing loss of water 
through evapotranspiration therefore creating water deficit between demand and supply. In order to forestall this effect, various cultural practices such as irrigation and the use of drought tolerant varieties had been put in place. NERICA is one of such low resource input rice varieties, which have proven to survive soil moisture stress (Jones, 1997a; Jones, 1997b). Crops have devised varied strategies to mitigate against the adverse effect of soil moisture stress; such as spatial escape from dehydration through changes in crop growing period to accommodate period of moisture availability. Other strategies include physical avoidance of dehydration through changes in the root architecture to explore deeper depth in search of water, tolerance of soil moisture stress with the active accumulation of compatible osmolyte, constitutive changes in the carbon assimilation and budgeting along the crop ontogeny and phylogeny. Recovery mechanism had been poorly understood after re-watering especially among the NERICA varieties. It is assumed that application of water after a spell of drought period could rejuvenate growth and may eventually influence the performance of rice. Recovery could be as a result of changes in rice's water status, thus facilitating cell expansion, eventually resulting in growth (Spollen and Sharp, 1991). Other mechanisms ascribed to accompany recovery include in hormonal balance (Hu \& al., 2012), dynamics of cavitation (Volker $\boldsymbol{\notin}$ al., 2003), and the activities of the scavengers of reactive oxygen radical ( $\mathrm{Lu}$ \& al., 2010), thus maintaining the structural integrity of the cell. Recovery is assumed to be dependent on the phenological phase, genotypic specific and aprion stress status of rice variety. Information on the recovery mechanism after moisture is restored is therefore required.
Phenotypic screening of NERICA for drought tolerance using recovery parameters could be less expensive. Thus the objective of this study was to examine growth and foliar character response and yield of some selected NERICA varieties to soil moisture stress at different phenological phase.

\section{MATERIALS AND METHODS Expeimental Site}

The pot experiment was conducted in the Screen house of the College of Plant Science and Crop Production, Federal University of Agriculture, Abeokuta in O ctober, 2011 (late season). The Screen house was covered with a plane glass for easy penetration of sunlight. Sides were covered with nets and the floor was cemented to prevent underground seepage of water. The soil used was a sandy loam soil from a fallowed soil ( $>$ five years), which permitted easy drainage of water and allows root respiration. Recommended full dose of phosphorus and potassium (30 kg ha-1) and half dose of nitrogen was applied to the soil as basal using $\mathrm{N}: \mathrm{P}: \mathrm{K}$ 15:15:15: fertilizer while the remaining half dose of nitrogen $(50 \mathrm{~kg}$ ha -1) was applied three weeks after planting using urea before imposition of stress (Oikeh $\&$ al., 2008).

\section{Cultural pradice}

Before planting, the soil was maintained to $100 \%$ field capacity using the gravimetric method:

\begin{tabular}{|c|}
\hline suturated soil weight - dry soll weight (air dried) \\
dry soil weight
\end{tabular} $100 \mathrm{O}$

Semi-coned buckets, filled with $10 \mathrm{~kg}$ of soil were watered to field capacity and allowed to drain; thereafter 2-3 seeds of each variety were planted per hole to a depth of about 2$3 \mathrm{~cm}$. The plants were thinned to one plant 
PHYSIOLO GICAL AND Y IELD RESPONSE OF SOME UPLAND RICE VARIETIES TO ..........

per stand, 10 days after sowing (DAS) to ensure consistency in data collection. The pots were maintained to field capacity for 21 days after which moisture stress was imposed. At the seedling stage the amount of water given to the pots daily were determined through weighing to determine water loss to evapotranspiration while at full canopy formation, watering was done based on rate of loss of soil moisture from the soil surface.

\section{Treatments and design}

Soil moisture stress was imposed on all the thirteen varieties at $21 \mathrm{DAS}, 50 \mathrm{DAS}$, and 70 DAS representing the three growth stages of rice (vegetative, reproductive and grain filling growth stages). Soil moisture stress was imposed once at a particular stage during the crop growth cycle of all stressed plants except the control. The duration of soil water deficit was 20 days for each growth stage after which watering was resumed to study the response of the rice plants to re-watering. The total of treatment combination was 234 pots per replicate. The pots were arranged in a completely randomised design.

\section{Samplingandmeasurements}

Data were collected at the end of moisture stress imposition on growth parameters (plant height, leaf area, number of leaves, number of tillers), and foliar physiological parameters (leaf rolling score, and leaf posture) at 0,7 , and 12 days after re-watering (DAR) at each growth stage of rice. Leaf area was determined as described by Gomez (1972), which is as follows:

Leaf area $=$ Leaf area of main culm $\times$ number of tillers/ hill $\times 0.67$, where

Leaf area of main culm $=$ length $\times$ breath. A three- point scale was used for leaf pos- ture (1-erect, 2-curved and 3-droopy) as described by Chang \& al., (1965). Similar scale was used on rolling (1-flat, 2-curved and 3totally rolled). Yield/ plant of each rice variety were taken at harvest maturity.

\section{Statistical analysis}

D ata collected were subjected to Analysis of Variance (ANOVA) at $5 \%$ probability level using Genstat 12th Edition. The treatment structure was added control (stress status) plus other treatments. Significant means were separated using D uncan Multiple Range Test (DMRT). All variables collected were checked for the violation of ANOVA assumption before analysis. Data on leaf rolling score and posture were transformed using square root transformation.

\section{RESULTS}

\section{Gronthreovery}

Significant interaction $(P<0.05)$ of stress status $\times$ growth stage $\times$ recovery period was observed on leaf area, plant height and number of leaves after re-watering (Tables 1, 2 and 3). All rice varieties under unstressed condition had significantly $(\mathrm{P}<0.05)$ higher leaf area than the stressed rice plants at all growth stages (Table 1). Under stressed condition at vegetative growth stage, rice varieties had increasing leaf area with increasing duration of re-watering. At other growth stages under stressed condition, rice varieties had similar leaf area with increasing duration of re-watering, which was significantly lower than LA at vegetative stage under stress condition. Rice varieties under unstressed condition were taller $(\mathrm{P}<0.05)$ than stressed condition for all growth stages. Under stressed condition for all growth stages there were no significant differences in the plant height of rice varieties with increasing duration of rewatering except at vegetative growth stage, where with increasing duration of re- 
O.S. SAKARIYAWO, S.O. OLAGUNJU, M.O. ATAYESE, K.A. OKELEYE, P.A.S. SOREMI, S.G. ADERIBIGBE, C.J OKONJI, A.A.

watering taller rice plants were observed. ber of leaves under stressed condition at all Similar pattern was observed on the num- growth stages (Tables 2 and 3).

Table 1: Interaction of stress status $\times$ growth stage $\times$ recovery period on leaf area of some selected rice varieties after re-watening

\begin{tabular}{lllllll}
\hline G rowth stage & Unstressed & & \multicolumn{3}{c}{ Stressed } \\
& 0 D AR & 7 D AR & 12 D AR & 0 D AR & 7 D AR & 12 DAR \\
\hline Vegetative & $42.22 \mathrm{~d}$ & $52.37 \mathrm{c}$ & $57.95 \mathrm{bc}$ & $21.08 \mathrm{e}$ & $31.57 \mathrm{~d}$ & $38.67 \mathrm{~d}$ \\
Reproductive & $64.97 \mathrm{ab}$ & $66.80 \mathrm{ab}$ & $66.20 \mathrm{ab}$ & $4.92 \mathrm{f}$ & $4.62 \mathrm{f}$ & $5.40 \mathrm{f}$ \\
Grain filling & $60.37 \mathrm{bc}$ & $74.80 \mathrm{a}$ & $61.86 \mathrm{bc}$ & $3.17 \mathrm{f}$ & $2.82 \mathrm{f}$ & $3.28 \mathrm{f}$ \\
\hline
\end{tabular}

a, b, c, d, e, f Means with same alphabets are not significantly different from one another at $1 \%$ probability level.

DAR - D ays after re-watering

Table 2: Interaction of stress status $\times$ growth stage $\times$ recovery period on plant height of some selected rice varieties after re-watering

\begin{tabular}{lllllll}
\hline Growth stage & $\begin{array}{l}\text { Unstressed } \\
\text { 0 DAR }\end{array}$ & 7 DAR & 12 DAR & $\begin{array}{l}\text { O DAR } \\
\text { V DARed }\end{array}$ & 7 DAR & 12 DAR \\
\hline Vegetative & $78.25 \mathrm{c}$ & $88.01 \mathrm{~b}$ & $92.67 \mathrm{~b}$ & $52.60 \mathrm{f}$ & $63.20 \mathrm{e}$ & $70.93 \mathrm{~d}$ \\
Reproductive & $104.87 \mathrm{a}$ & $106.86 \mathrm{a}$ & $108.50 \mathrm{a}$ & $8.21 \mathrm{gh}$ & $8.62 \mathrm{gh}$ & $10.67 \mathrm{~g}$ \\
Grain filling & $108.11 \mathrm{a}$ & $108.55 \mathrm{a}$ & $108.53 \mathrm{a}$ & $5.84 \mathrm{gh}$ & $4.55 \mathrm{~h}$ & $5.21 \mathrm{gh}$ \\
\hline
\end{tabular}

a, b, c, d, e, f Means with same alphabets are not significantly different from one another at $1 \%$ probability level.

DAR - D ays after re-watering

Table 3: Interaction of stress status $\times$ growth stage $\times$ recovery period on number of Leaves of some selected rice varieties after re-watering

\begin{tabular}{lllllll}
\hline Growth stage & Unstressed & & & Stressed & \\
& 0 DAR & 7 DAR & 12 DAR & 0 DAR & 7 DAR & 12 DAR \\
\hline Vegetative & $13.85 \mathrm{~b}$ & $14.96 \mathrm{~b}$ & $17.13 \mathrm{~b}$ & $6.86 \mathrm{~d}$ & $9.55 \mathrm{c}$ & $18.77 \mathrm{~b}$ \\
Reproductive & $28.50 \mathrm{a}$ & $29.33 \mathrm{a}$ & $30.13 \mathrm{a}$ & $1.31 \mathrm{e}$ & $1.13 \mathrm{e}$ & $1.54 \mathrm{e}$ \\
Grain filling & $31.18 \mathrm{a}$ & $31.87 \mathrm{a}$ & $32.87 \mathrm{a}$ & $0.46 \mathrm{e}$ & $0.41 \mathrm{e}$ & $0.51 \mathrm{e}$ \\
\hline
\end{tabular}

a, b, c, d, e, f Means with same alphabets are not significantly different from one another at $1 \%$ probability level. 
PHYSIOLO GICAL AND Y IELD RESPONSE OF SOME UPLAND RICE VARIETIES TO .........

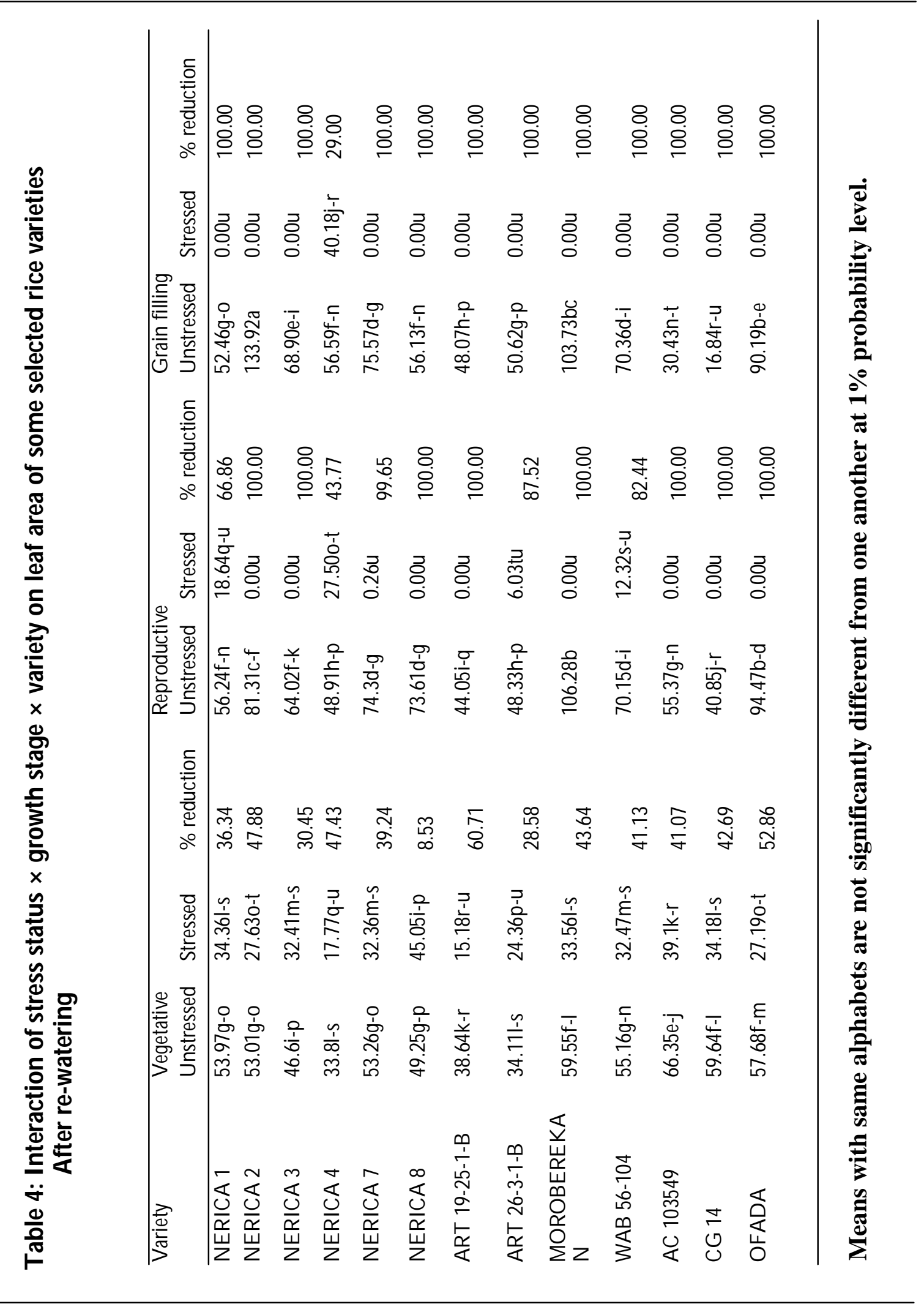

J. Agric. Sci. \& Env. 2015, 15(1):93-111 
DAR- Days after re-watering

Significant interaction $(P<0.05)$ of stress status $x$ growth stage $x$ variety was observed on leaf area, plant height, number of leaves and number of tillers (Tables 4, 5, 6 and 7). At all growth stages, rice varieties under unstressed condition had significantly higher leaf area than rice varieties under stressed condition. There was a depression in leaf area of rice varieties under stressed condition with age, which was most pronounced at grain filling stage, except NERICA 4 that had increase in leaf area. At vegetative growth stage NERICA 8 had the least percentage reduction in leaf area than others, while the highest was observed in ART 19-25-1-B. At reproductive and grain filling growth stages NERICA 4 had the least percentage reduction in leaf area, while most varieties had similar percentage reduction at both growth stages (Table 4).

All the rice varieties under unstressed condition were significantly $(\mathrm{P}<0.05)$ taller than rice varieties under stress condition. There was a reduction in plant height among rice varieties under stress condition at all growth stages, except NERICA 4. At vegetative growth stage NERICA 7 had the least percentage reduction in plant height than other rice varieties, while Ofada rice variety had the highest percentage reduction in plant height than others.

Percentage reduction in plant height observed at reproductive and grain filling stage indicated that NERICA 4 had the least, while other rice varieties had comparatively similar percentage reduction at both growth stages (Table 5).
Rice varieties under unstressed condition had significantly higher number of leaves than rice varieties under stress condition. For most rice varieties under stress condition it was observed that there was a significant decrease in the number of leaves with growth stages. At vegetative growth stage, under stressed condition, most rice varieties had a depression in the number of leaves, the least percentage decrease in the number of leaves was observed in NERICA 7, while the highest percentage decrease in the number of leaves was observed in NERICA 3. However, some rice varieties (O fada, NERICA 8 and Moroberekan) at vegetative growth stage under stressed condition had a percentage gain in the number of leaves. At reproductive growth stage under stressed condition most varieties had $100 \%$ reduction in the number of leaves except NERICA 1 and NERICA 4. Under stress condition, at grain filling stage all the rice varieties had a total loss of leaves (Table 6).

At vegetative growth stage, most rice varieties under stressed condition had a reduction in the number of tillers, except some (NERICA 7, Moroberikan and WAB 56104) that expressed a gain in the number of tillers. Under stressed condition most varieties at reproductive growth stage had total reduction in the number of tillers except NERICA 4 that had a gain in the number of tillers. Similar pattern in the number of tillers under stressed condition was observed at grain filling stage, except that NERICA 4 had no loss in the number of tillers (Table 7). 
HYSIOLO GICAL AND YIELD RESPONSE OF SOME UPLAND RICE VARIETIES TO .........

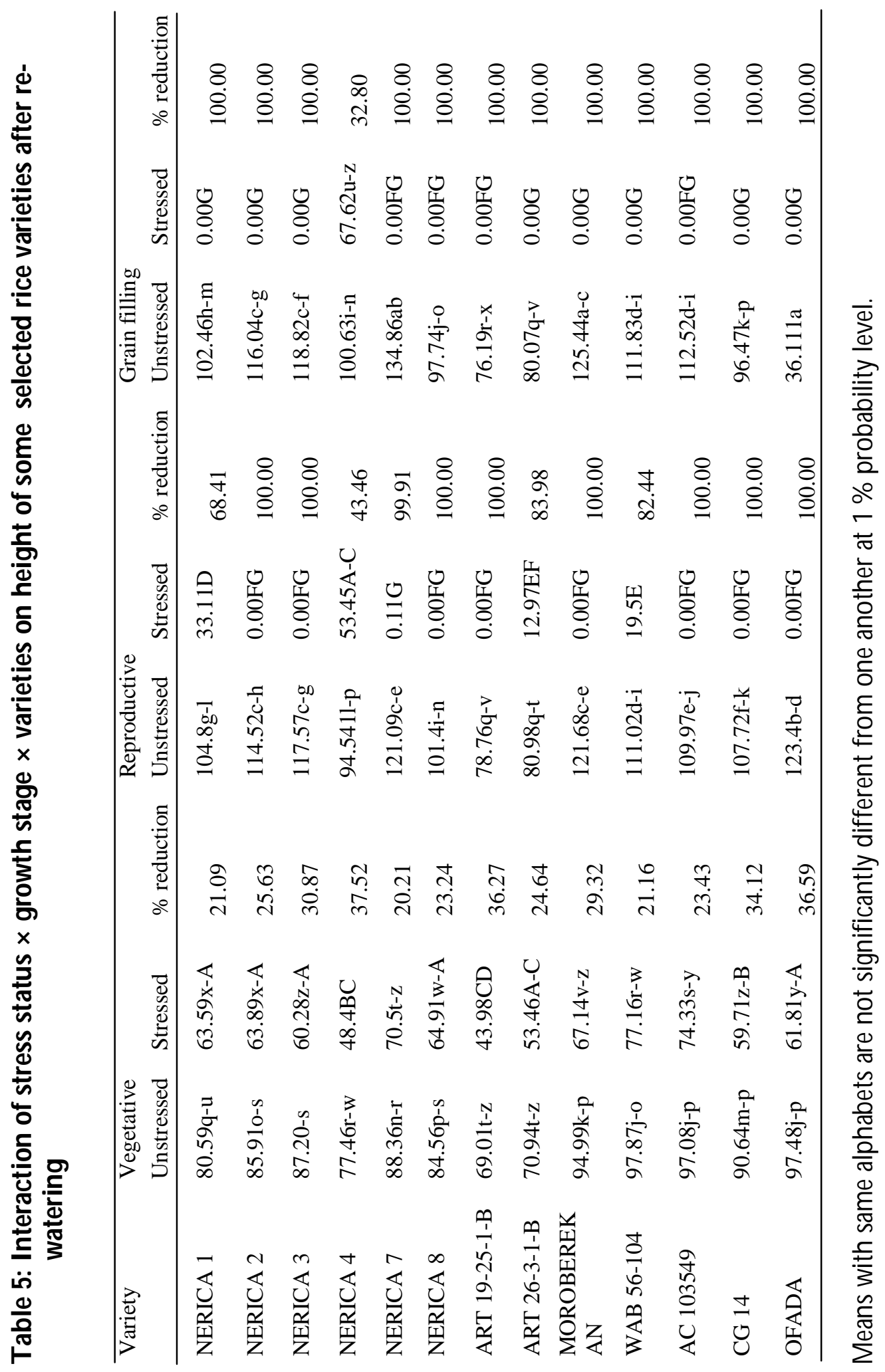

J. Agric. Sci. \& Env. 2015, 15(1): 93-111 
PHYSIOLO GICAL AND Y IELD RESPONSE OF SOME UPLAND RICE VARIETIES TO .........

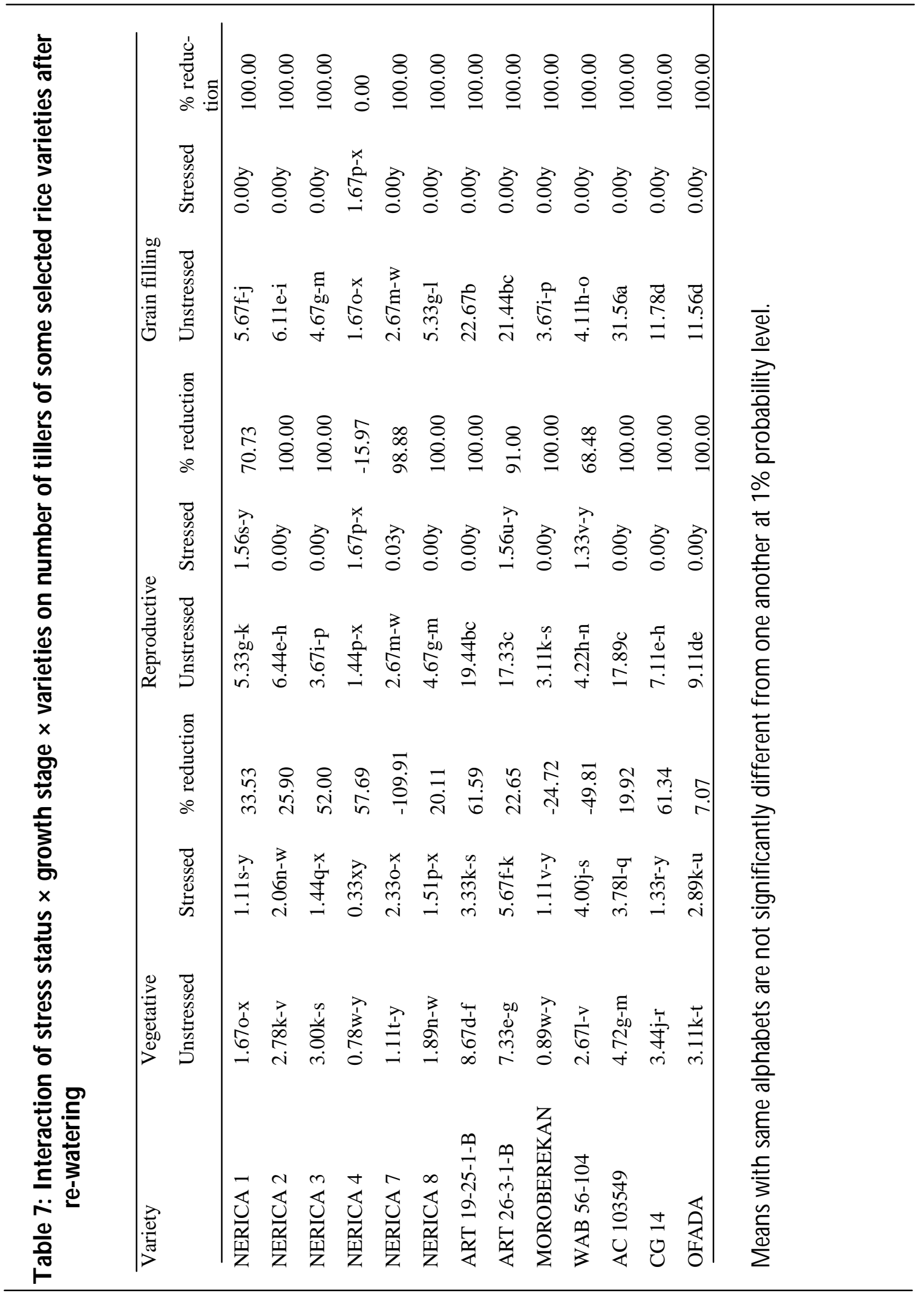

J. Agric. Sci. \& Env. 2015, 15(1): 93-111

101 
Fdiar physidogical dharader recouty

Significant interaction $(P<0.05)$ of stress status $\times$ growth stage $\times$ recovery period was observed on leaf posture after rewatering (Table 8). Under unstressed condition at all growth stages, all rice varieties had a curved leaf posture with increasing duration of re-watering. Under stressed condition at vegetative growth stage with increasing duration of re-watering most rice varieties had curved leaf posture except at 7 DAR, when the leaves were erect. However, at later growth stages under stressed condition with increasing duration of re-watering most rice varieties had erect posture except at the beginning of re-watering when most of them had a curved leaf posture (Table 8).

Table 8: Interaction of stress status $\times$ growth stage $\times$ recovery period on Leaf posture of some selected rice varieties after re-watering

\begin{tabular}{lllllll}
\hline $\begin{array}{l}\text { Growth } \\
\text { stage }\end{array}$ & $\begin{array}{l}\text { Unstressed } \\
\text { 0 DAR }\end{array}$ & 7 D AR & 12 D AR & $\begin{array}{l}\text { Stressed } \\
\text { 0 D AR }\end{array}$ & 7 D AR & 12 D AR \\
\hline Vegetative & $2.12 \mathrm{~b}$ & $1.97 \mathrm{~b}$ & $2.00 \mathrm{~b}$ & $2.05 \mathrm{~b}$ & $1.68 \mathrm{c}$ & $1.97 \mathrm{~b}$ \\
$\begin{array}{l}\text { Reproduc- } \\
\text { tive }\end{array}$ & $2.00 \mathrm{~b}$ & $2.00 \mathrm{~b}$ & $2.00 \mathrm{~b}$ & $2.88 \mathrm{a}$ & $0.23 \mathrm{de}$ & $0.30 \mathrm{~d}$ \\
Grain filling & $2.00 \mathrm{~b}$ & $2.00 \mathrm{~b}$ & $2.00 \mathrm{~b}$ & $2.92 \mathrm{a}$ & $0.15 \mathrm{e}$ & $0.15 \mathrm{e}$ \\
\hline
\end{tabular}

a, b, c, d, e, f Means with same alphabets are not significantly different from one another at $1 \%$ probability level

There was a significant interaction $(\mathrm{P}<$ 0.05 ) of stress status $\mathrm{x}$ growth stage $\times$ recovery period on leaf rolling score (Table 9). At all growth stages under unstressed condition, all the rice varieties had flat leaves. Under stressed condition at all

Table 9: Interaction of stress status $\times$ growth stage $\times$ recovery period on leaf rolling score of some selected rice varieties after re-watering

\begin{tabular}{lllllll}
\hline Growth stage & Unstressed & \multicolumn{5}{c}{ Stressed } \\
& 0 DAR & 7 DAR & 12 DAR & 0 DAR & 7 DAR & 12 DAR \\
\hline Vegetative & $1.14 \mathrm{c}-\mathrm{e}$ & $1.36 \mathrm{c}$ & $1.00 \mathrm{de}$ & $2.04 \mathrm{~b}$ & $1.21 \mathrm{~cd}$ & $1.15 \mathrm{c}-\mathrm{e}$ \\
Reproductive & $1.00 \mathrm{de}$ & $1.00 \mathrm{de}$ & $1.00 \mathrm{de}$ & $2.86 \mathrm{a}$ & $0.31 \mathrm{f}$ & $0.17 \mathrm{fg}$ \\
Grain filling & $1.00 \mathrm{de}$ & $1.00 \mathrm{de}$ & $1.00 \mathrm{de}$ & $2.92 \mathrm{a}$ & $0.13 \mathrm{~g}$ & $0.08 \mathrm{~g}$ \\
\hline
\end{tabular}

a, b, c, d, e, f Means with same alphabets are not significantly different from one another at $1 \%$ probability level. 


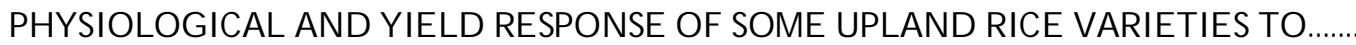

Leaf posture was significantly $(\mathrm{P}<0.05)$ ture. Similar leaf posture was displayed by affected by the interaction of stress status $\times$ CG 14 and AC 103549. Under stressed congrowth stage $x$ variety (Table 10). At all dition at reproductive and grain filling stage growth stages under unstressed condition most varieties had erect leaf posture after remost rice varieties had curved leaf posture. watering, except NERICA 4 that still mainUnder stressed condition, at vegetative tained curved leaf posture under stressed growth stage most rice cultivars had erect condition at grain filling stage.

leaf posture except O fada with curved pos-

Table 10: Interaction of stress status $\times$ growth stage $\times$ variety on leaf posture of some selected rice varieties after re-watering

\begin{tabular}{lllllll}
\hline Variety & Vegetative & \multicolumn{3}{c}{ Reproductive } & Grain filling \\
& Unstressed & Stressed & Unstressed & Stressed & Unstressed & Stressed \\
\hline NERICA 1 & $2.00 \mathrm{a}-\mathrm{e}$ & $1.83 \mathrm{a}-\mathrm{f}$ & $2.00 \mathrm{a}-\mathrm{e}$ & $1.22 \mathrm{~h}$ & $2.00 \mathrm{a}-\mathrm{e}$ & $1.00 \mathrm{i}$ \\
NERICA 2 & $2.00 \mathrm{a}-\mathrm{e}$ & $1.72 \mathrm{c}-\mathrm{f}$ & $2.00 \mathrm{a}-\mathrm{e}$ & $1.00 \mathrm{i}$ & $2.00 \mathrm{a}-\mathrm{e}$ & $1.00 \mathrm{i}$ \\
NERICA 3 & $1.89 \mathrm{a}-\mathrm{f}$ & $1.67 \mathrm{~d}-\mathrm{f}$ & $2.00 \mathrm{a}-\mathrm{e}$ & $1.00 \mathrm{i}$ & $2.00 \mathrm{a}-\mathrm{e}$ & $1.00 \mathrm{i}$ \\
NERICA 4 & $2.00 \mathrm{a}-\mathrm{e}$ & $1.89 \mathrm{a}-\mathrm{f}$ & $2.00 \mathrm{a}-\mathrm{e}$ & $1.67 \mathrm{df}$ & $2.00 \mathrm{a}-\mathrm{e}$ & $2.00 \mathrm{a}-\mathrm{e}$ \\
NERICA 7 & $2.00 \mathrm{a}-\mathrm{e}$ & $2.00 \mathrm{a}-\mathrm{e}$ & $2.00 \mathrm{a}-\mathrm{e}$ & $1.00 \mathrm{i}$ & $2.00 \mathrm{a}-\mathrm{e}$ & $1.00 \mathrm{i}$ \\
NERICA 8 & $2.00 \mathrm{a}-\mathrm{e}$ & $1.83 \mathrm{a}-\mathrm{f}$ & $2.00 \mathrm{a}-\mathrm{e}$ & $1.00 \mathrm{i}$ & $2.00 \mathrm{a}-\mathrm{e}$ & $1.00 \mathrm{i}$ \\
ART 19-25-1-B & $2.00 \mathrm{a}-\mathrm{e}$ & $1.89 \mathrm{a}-\mathrm{f}$ & $2.00 \mathrm{a}-\mathrm{e}$ & $1.00 \mathrm{i}$ & $2.00 \mathrm{a}-\mathrm{e}$ & $1.00 \mathrm{i}$ \\
ART 26-3-1-B & $2.00 \mathrm{a}-\mathrm{e}$ & $2.11 \mathrm{ab}$ & $2.00 \mathrm{a}-\mathrm{e}$ & $1.56 \mathrm{~g}$ & $2.00 \mathrm{a}-\mathrm{e}$ & $1.00 \mathrm{i}$ \\
MOROBEREK & $2.11 \mathrm{a}-\mathrm{e}$ & $1.78 \mathrm{a}-\mathrm{f}$ & $2.00 \mathrm{a}-\mathrm{e}$ & $1.00 \mathrm{i}$ & $2.00 \mathrm{a}-\mathrm{e}$ & $1.00 \mathrm{i}$ \\
AN & & & & & & $1.00 \mathrm{i}$ \\
WAB 56-104 & $2.00 \mathrm{a}-\mathrm{e}$ & $1.78 \mathrm{~b}-\mathrm{f}$ & $2.00 \mathrm{a}-\mathrm{e}$ & $1.33 \mathrm{gh}$ & $2.00 \mathrm{a}-\mathrm{e}$ & $1.00 \mathrm{i}$ \\
AC 103549 & $2.17 \mathrm{a}$ & $2.11 \mathrm{a}-\mathrm{c}$ & $2.00 \mathrm{a}-\mathrm{e}$ & $1.00 \mathrm{i}$ & $2.00 \mathrm{a}-\mathrm{e}$ & $1.00 \mathrm{i}$ \\
CG 14 & $2.11 \mathrm{de}$ & $2.00 \mathrm{a}-\mathrm{c}$ & $2.00 \mathrm{a}-\mathrm{e}$ & $1.00 \mathrm{i}$ & $2.00 \mathrm{a}-\mathrm{e}$ & \\
\hline
\end{tabular}

a, b, c, d, e, f Means with same alphabets are not significantly different from one another at $1 \%$ probability level.

Significant interaction $(\mathrm{P}<0.05)$ of stress status $x$ growth stage $x$ variety was observed on leaf rolling score (Table 11). Under stressed and unstressed condition at vegetative growth stage, the leaf flat, however it was observed that ART 26-3-1-B under stressed condition had a curved leaf, which was also observed in WAB 56-104, AC 103549, CG 14 and Ofada. The leaf was flat under stressed and unstressed condition at both reproductive and grain filling stage for all the rice varieties after re-watering, except NERICA 4 had curved leaf under stress condition at both reproductive and grain filling stage.

Imposition of soil moisture stress significantly affected all varieties investigated; how- 
ever among the stressed varieties NERICA moisture stress, while maximum reduction in 8 (5.75 g plant-1) had the highest yield/ grain yield/ plant with imposition of moisture plant, which was not significantly different stress was observed in NERICA 1 (86 \%). from other varieties (Table 12). NERICA 8 Variety AC 103549 and CG 14 had a perequally had the least percentage reduction centage increase in grain yield under stress on grain yield (5\%) with the imposition of condition

\section{Table 11: Interaction of stress status $\times$ growth stage $\times$ variety on leaf Rolling score of some selected rice varieties after re-watering}

\begin{tabular}{|c|c|c|c|c|c|c|}
\hline \multirow[t]{2}{*}{ Variety } & \multicolumn{2}{|l|}{ Vegetative } & \multicolumn{2}{|l|}{ Reproductive } & \multicolumn{2}{|l|}{ Grain filling } \\
\hline & $\begin{array}{l}\text { Un- } \\
\text { stressed }\end{array}$ & Stressed & Unstressed & Stressed & $\begin{array}{l}\text { Un- } \\
\text { stressed }\end{array}$ & Stressed \\
\hline NERICA 1 & $1.11 \mathrm{f}-\mathrm{i}$ & $1.22 \mathrm{~d}-\mathrm{h}$ & $1.00 \mathrm{~g}-\mathrm{i}$ & $1.00 \mathrm{hi}$ & $1.00 \mathrm{~g}-\mathrm{i}$ & $1.00 \mathrm{i}$ \\
\hline NERICA 2 & $1.00 \mathrm{~g}-\mathrm{i}$ & $1.33 \mathrm{~b}-\mathrm{g}$ & $1.00 \mathrm{~g}-\mathrm{i}$ & $1.00 \mathrm{i}$ & $1.00 \mathrm{~g}-\mathrm{i}$ & $1.00 \mathrm{i}$ \\
\hline NERICA 3 & $1.44 \mathrm{a}-\mathrm{g}$ & $1.17 \mathrm{~d}-\mathrm{h}$ & $1.00 \mathrm{~g}-\mathrm{i}$ & $1.00 \mathrm{i}$ & $1.00 \mathrm{~g}-\mathrm{i}$ & $1.00 \mathrm{i}$ \\
\hline NERICA 4 & $1.00 \mathrm{~g}-\mathrm{i}$ & $1.28 \mathrm{c}-\mathrm{g}$ & $1.00 \mathrm{~g}-\mathrm{i}$ & 1.83a & $1.00 \mathrm{~g}-\mathrm{i}$ & 2.56a-f \\
\hline NERICA 7 & $1.00 \mathrm{~g}-\mathrm{i}$ & $1.00 \mathrm{~g}-\mathrm{i}$ & $1.00 \mathrm{~g}-\mathrm{i}$ & $1.00 \mathrm{i}$ & $1.00 \mathrm{~g}-\mathrm{i}$ & $1.00 \mathrm{i}$ \\
\hline NERICA 8 & $1.00 \mathrm{~g}-\mathrm{i}$ & $1.50 \mathrm{a}-\mathrm{f}$ & $1.00 \mathrm{~g}-\mathrm{i}$ & $1.00 \mathrm{i}$ & $1.00 \mathrm{~g}-\mathrm{i}$ & $1.00 \mathrm{i}$ \\
\hline ART 19-25-1-B & $2.22 \mathrm{a}-\mathrm{c}$ & $1.67 a-e$ & $1.00 \mathrm{~g}-\mathrm{i}$ & $1.00 \mathrm{i}$ & $1.00 \mathrm{~g}-\mathrm{i}$ & $1.00 \mathrm{i}$ \\
\hline ART 26-3-1-B & $1.00 \mathrm{~g}-\mathrm{i}$ & $2.00 \mathrm{~b}$ & $1.00 \mathrm{~g}-\mathrm{i}$ & $1.39 \mathrm{e}-\mathrm{h}$ & $1.00 \mathrm{~g}-\mathrm{i}$ & $1.00 \mathrm{i}$ \\
\hline MOROBEREKAN & $1.00 \mathrm{~g}-\mathrm{i}$ & $1.33 \mathrm{~b}-\mathrm{g}$ & $1.00 \mathrm{~g}-\mathrm{i}$ & $1.00 \mathrm{i}$ & $1.00 \mathrm{~g}-\mathrm{i}$ & $1.00 \mathrm{i}$ \\
\hline WAB 56-104 & $1.11 \mathrm{f}-\mathrm{i}$ & $1.67 a-d$ & $1.00 \mathrm{~g}-\mathrm{i}$ & $1.22 g-i$ & $1.00 \mathrm{~g}-\mathrm{i}$ & $1.00 \mathrm{i}$ \\
\hline AC 103549 & $1.17 \mathrm{~d}-\mathrm{h}$ & $1.67 \mathrm{a}-\mathrm{c}$ & $1.00 \mathrm{~g}-\mathrm{i}$ & $1.00 \mathrm{i}$ & $1.00 \mathrm{~g}-\mathrm{i}$ & $1.00 \mathrm{i}$ \\
\hline CG 14 & $1.11 \mathrm{f}-\mathrm{i}$ & $1.67 \mathrm{a}-\mathrm{d}$ & $1.00 \mathrm{~g}-\mathrm{i}$ & $1.00 \mathrm{i}$ & $1.00 \mathrm{~g}-\mathrm{i}$ & $1.00 \mathrm{i}$ \\
\hline OFADA & $1.00 \mathrm{~g}-\mathrm{i}$ & 1.56a-f & $1.00 \mathrm{~g}-\mathrm{i}$ & $1.00 \mathrm{i}$ & $1.00 \mathrm{~g}-\mathrm{i}$ & $1.00 \mathrm{i}$ \\
\hline
\end{tabular}

a, b, c, d, e, f Means with same alphabets are not significantly different from one another at $1 \%$ probability level.

Table 12: Interaction of stress status $\times$ variety on yield/ plant $(\mathrm{kg})$ of rice

$\begin{array}{lllll}\text { Variety } & \text { Unstressed } & \text { Stressed } & \text { \% Reduction } & \text { \% Increase } \\ \text { NERICA } 1 & 15.79 \mathrm{~b} & 2.28 \mathrm{fg} & 85.56 & - \\ \text { NERICA 2 } & 21.45 \mathrm{a} & 4.63 \mathrm{c}-\mathrm{g} & 78.11 & - \\ \text { NERICA 3 } & 8.94 \mathrm{c} & 4.01 \mathrm{c}-\mathrm{g} & 55.15 & - \\ \text { NERICA } 4 & 7.36 \mathrm{cdef} & 2.25 \mathrm{fg} & 69.43 & - \\ \text { NERICA } 7 & 8.98 \mathrm{c} & 3.03 \mathrm{efg} & 66.26 & - \\ \text { NERICA } 8 & 6.05 \mathrm{c}-\mathrm{g} & 5.75 \mathrm{c}-\mathrm{g} & 4.96 & - \\ \text { ART 19-25-1-B } & 15.79 \mathrm{~b} & 4.54 \mathrm{c}-\mathrm{g} & 71.25 & - \\ \text { ART 26-3-1-B } & 9.22 \mathrm{c} & 5.49 \mathrm{c}-\mathrm{g} & 40.46 & - \\ \text { MORO BEREKAN } & 7.85 \mathrm{cde} & 2.49 \mathrm{efg} & 68.28 & - \\ \text { WAB 56-104 } & 8.67 \mathrm{~cd} & 3.78 \mathrm{c}-\mathrm{g} & 56.40 & - \\ \text { AC 103549 } & 2.67 \mathrm{efg} & 2.77 \mathrm{efg} & - & 3.74 \\ \text { CG 14 } & 0.81 \mathrm{~g} & 1.32 \mathrm{~g} & - & 62.96 \\ \text { OFADA } & 7.71 \mathrm{cdef} & 3.44 \mathrm{~d}-\mathrm{g} & 55.38 & -\end{array}$

a, b, c, d, e, f Means with same alphabets are not significantly different from one another at $1 \%$ 
PHYSIOLO GICAL AND Y IELD RESPONSE OF SOME UPLAND RICE VARIETIES TO .........

\section{DISCUSSION}

This trial indicates that re-watering after soil moisture stress significantly affected growth and yield of some selected upland rice varieties. In the course of its ontogeny, crop plants have devised various strategies for coping with abiotic stress, recovery mechanism inclusive. This strategy could be used as one of the criteria for screening for moisture stress.

Under stressed condition all the growth parameters (leaf area, plant height and number of leaves) at all growth stages were stable in rice varieties with increasing duration after re-watering except at vegetative growth stage, where there was a significant increase in growth with increasing duration after rewatering. Vegetative growth stage have been characterised as the period with significant increase in growth, this would have indicated the response observed at this growth stage (Taiz and Zeiger, 2003). Effect of re-watering on the growth of rice varieties that were earlier subjected to soil moisture stress could be attributed to improvement in the cellular water status of rice varieties especially at vegetative growth stage. This effect is mostly reflected on the cellular turgor pressure, subsequently implicated on cellular expansion (Spollen and Sharp, 1991). Among the processes involved in growth at the cellular level is cell expansion. This process is dependent on turgor pressure (Spollen and Sharp, 1991) and rheological properties of the cell (Lockhart, 1965). MacAdam \& al., (1992) opined that soil moisture stress could to lead to tightening of the cell wall. It could be inferred that re-watering must have delayed cell wall tightening, increasing the window of response to leaf area growth after re-watering in all the investigated upland rice varieties (Lechner \& al., 2008). Other factors could have influenced the rheological properties of cell wall after re-watering, such as activity of cell wall peroxidase (MacAdam, 1992; Thompson, 1998) and expansin (Catala $\&$ al; 2000; Belfield $\notin a \mathrm{al}$, 2005). However, nexus between re-watering and the activities of these molecules could not be established in this study.

Meanwhile, under stressed condition rice varieties foliar characters (leaf posture and leaf rolling score), a proximate indicator of water status in cereals indicated erect leaf posture, stable and flat leaf surface at all growth stages with increasing duration after re-watering. Erect leaf posture and a flat assimilatory surface with increasing duration of re-watering could have positively altered the leaf water status. Available literature had indicated that erectophile leaf posture could alter attenuation of light in the canopy, especially interception of diffuse light into the canopy, thus increasing the photosynthetic capacity of the rice varieties after re-watering (Monneveux \& al., 2004; Innes and Black, 1983). Similar argument could be suggested with respect to flat leaf surface. Increased leaf surface after re-watering would aid water and gas exchange in all the rice varieties at all growth stages, consequently affecting rice varieties productivity that were earlier subjected to soil moisture stress but later recovered its growth through re-watering.

Under stress condition, at different growth stages varietal differences was observed on the leaf area, number of leaves, number of tillers and plant height. Better assimilatory surface observed in NERICA 4 under stress condition especially at reproductive and grain filling growth stages could be premised on the reduced percentage reduction in those growth parameters. With comparatively higher assimilatory surface there is the ten- 
dency that it would ensure capture of more radiant energy, especially diffused ones with taller NERICA 4 rice cultivar under moisture stress at reproductive and grain filling stages. These stages had earlier been reported to be the growth stage most cereals are susceptible to stressors (Zinolabedin \& al., 2008). Varietal variability, stress status and growth stage could have informed differences in growth responses.

Leaf posture of most rice varieties was stable when subjected to soil moisture stress at vegetative growth stage. However at other growth stages (reproductive and grain filling stages) most of the rice varieties had a more erect leaf posture under stress than the slanted canopy architecture under unstressed condition at both growth stages. NERICA 4 under soil moisture stress condition was able to sustain a stable canopy architecture (dropped leaf posture) at reproductive and grain filling stages. Leaf rolling response for all the rice varieties at vegetative growth stage was similar under soil moisture, which was predominantly flat for most rice varieties. However, NERICA under soil moisture stress at both reproductive and grain filling growth stages maintained a curved leaf. This response is very typical of the grass family when they are under soil moisture stress. A curved leaf in this context is to reduce assimilatory surface thus reducing the amount of water loss into the atmosphere when the supply of water is disrupted compared to its demand. One could infer that NERICA 4 had devised a mechanism to escape the negative influence of soil moisture stress xylem water potential status. Available literature indicated that soil moisture stress could result in reduced water potential of the xylem, resulting in an increased xylem cavitation (Tyree $\mathbb{E}$ al, 1986). Increased xylem cavitation could re- duce hydraulic conductance of rice, recursively leading to further reduction of xylem water potential, exacerbating negatively hydraulic property of the xylem. This could be one of the constraints in reduced stomata conductance (Galle $\notin$ al., 2009). The foliar response of NERICA 4 could have predisposes it to reduced transpiration and gas exchange, compromising photosynthetic efficiency and ultimately yield. But NERICA 4 compensated for this after re-watering with a higher number of tillers and leaf area that could allow it to intercept more radiant energy for photosynthesis.

Apart from the cavitation dynamics that could have changed the water status of NERICA 4 towards a better growth after rewatering, other factors had been suggested in the literature to aid hydraulic properties of the plant during plant adaptation to stress or at recovery stage (Catala $\mathrm{e}$ al, 2000; Belfield, 2005; MacAdam \& al,, 1992; Pierre \& al, 2002). Such factors include activities of scavengers of reactive oxygen radicals that have been reported to be activated during rewatering in ensuring structural integrity of the cell against photoinhibition ( $\mathrm{Lu} \notin \mathrm{al}$., 2010). Activities of aquaporin and increase in root pressure are some of the factors that were earlier reported in the literature to facilitate hydraulic conductance of rice plant positively during moisture stress and recovery (Pierre et al., 2002; Miller, 1985; Tyree et al., 1986; Sperry \& al., 1987; Picard, 1989; Cochard \& al, 1994). It could be suggested that NERICA 4 could have used this mechanism during its recovery process apart from the growth and foliar characters response observed in this trial.

The yield response to moisture stress in all varieties indicated that there was no significant difference among them. This could sug- 
HYSIOLOGICAL AND YIELD RESPONSE OF SOME UPLAND RICE VARIETIES TO .........

gest that there could be a trade-off between performance and recovery to moisture stress. NERICA 4 that had a better growth after recovery did not perform better than other varieties with respect to yield. It must have placed a high premium on its resistance to soil moisture stress at the expense of yield per plant. Meanwhile, with respect to percentage reduction in yield NERICA 8 had the least (4.96\%), which had higher growth rate at the beginning of its growth stage, especially at the vegetative phase in contrast to NERICA 4. This could have suggested availability of photosynthates to NERICA 8 to ensure survivability at the most critical stage of its developments (reproductive stage).

This study was limited by the availability of physiological parameters to elucidate underlying mechanism responsible for the recovery mechanism of the selected upland variety when subjected to stress at different growth phases.

In conclusion, at vegetative growth stage all growth parameters recovered, leaf posture was erect and assimilatory surface was flat with increasing duration of re-watering in rice varieties earlier subjected to soil moisture stress. Conversely, growth parameters, leaf posture and assimilatory surface were stable with increasing duration of rewatering at reproductive and grain filling stages in rice varieties earlier subjected to soil moisture stress. NERICA 4 had more growth, adaptive canopy architecture than other varieties at all growth stages under moisture stress condition. Recovery parameters could be used for screening upland rice, apart from other resistance parameters, with respect to soil moisture stress.

\section{ACKNOWLEDGEMENTS}

This project was funded by Agricultural Research Council of Nigeria (ARCN) through RFA 4.20.

\section{REFERENCES}

Austin, R.B. 1989. Prospet for improing arop production in stressfil enviranments E dited by I.J. Flowers and M.B. Jones H.G. Jones. Cambridge: Cambridge University Press.

Belfield, EJ, Ruperti, B, Roberts, JA, McQ ueen-Mason, J. 2005. Changes in expansin activity and gene expression during ethylene-promoted leaf abscission in Sambucus negra. Joumal of Experimental Bdany 56: $817-823$.

Catala, C., Rose, J.K.C., Bennett, A.B. 2000. Auxin-regulated genes encoding cell wall-modyfying proteins are expressed during early tomato fruit growth. Plant Physidogy 122: 527 - 534.

Chang, T.T., Bardenas, E.A., Amulfo, C., Rosario, D. 1965. The morphology and varietal characteristics of the rice plant. Teehnical Bullein4 December, the International Rice Research Institute, Los Banos, Laguna, the Philippines.

Cheves, M.M., Maroco, J.P., Pereira, J.S. 2003. Understanding plant response to drought-from genes to the whole plant. Func tional Plant Bidogy30: 239 - 264.

Cochard, H., Ewers, F.W., Tyree, M.T. 1994.Water relations of a tropical vine-like bamboo (Rhipidocladum racemiflorum): root pressures, vulnerability to cavitation and seasonal changes in embolism. Jaumal of Expeimental Bdany 45: 1085 - 1089.

Galle, A., Florez-Sarasa, T., Tomas, M., 
Pou, A., Medraino, H., Ribas-Carbo, M., Flexas, J. 2009. The role of mesophyll conductance during water stress and recovery in tobacco (Nicotiana sylvestris): Acclimation or limitation. Jaumal of Experimental Bdany60(8): 2379 - 2390.

Gomez, K.A. 1972. Teehniques for fidd expeiments with rice International Rice Research Institute, Los Banos, Philppines.

Hu., L., Wang, Z., Huang, B. 2012.G rowth and Physiological recovery of kentucky Bluegrass from drought stress as affected by a synthetic cytokinin 6-Benzylaminopurine. Crop Saiene52: 2331 - 2340.

Innes, P., Blackwell, R.D. 1983. Some effects of leaf posture on the yield and water economy of wheat. Jaumal of Agialtural Saiene101:367-376.

Jones, M.P., Dingkuhn, M., Aluko, G.K., Mande, S. 1997a. Interspecific Oryza sativa 0 . glabberima steud progenies in ipland ricr improvement. Euphytica 92: 237 246.

Jones, M.P., Mande, S., Aluko, K. 1997b. Diversity and potantial of Oryza glabberima Steud. in lowland rice breeding. Breeding Saene 47: 395 - 398.

Lechner, L., Gustavo, A., Pereyra-Irujo., Grainer, S., Aguimezabal, L.A.N. 2008. Rewatering plants after a long water deficit treatment reveals that leaf epidermal cells retain their ability to expand after the leaf has apparently reached its final size. Amals of Bdany 101: 1007 - 1025.

Lockhart, J.A. 1965. Analysis of a reversible plant cell elongation. Jamal of Theretical Bidogy;: 264 - 275.
Lu, Y., Deng, X., Kwak, S. 2010. Over eXpression of CuZn Superoxide dismutase (CuZnSOD) and Ascorbate Peroxidase (APX) in transgenic sweet potato enhances tolerance and recovery from drought stress. African Jaumal of Bidtedmolog. 9(46): 8378 8391.

MacAdam, J.N., Nelson, C.J., Sharp, R.E. 1992. Peroxidase activity in the leaf elongation zone of tall fescue:I. Spatial distribution of ionically bound peroxidase activity in genotype differing in length of elongation zone. Plant Physidogy99: 872 - 873.

Miller, D.M. 1985. Studies of root function in Zea mays: III. Xylem sap composition at maximum root pressure provides evidence of active transport into the xylem and a measurement of the reflection coefficient of the root. Plant Physidoy 13: 383 - 388.

Monneveux, P., Reynolds, M.P., Gonzalez-Santoyo, H., Pena, R.J., Mayr, L., Zapata, F. 2004. Relationship between grain yield, leaf morphology, carbon isotope discrimination and ash content in irrigated wheat. Jaumal of Agrommy and Crop Saence 190:395-401.

Oikeh, S.O., Nwilene, F.E., Agunbiade, T.A., Oladimeji, 0., Ajayi, 0., Semon, M., T sunematsu, H., Samejima, H. 2008. Growing upland rice: A production handbook Africa Rice Centre. AfricaRice, Cotonou, Benin, 44pp.

Picard, W.F. 1989. How might a tracheary element is embolized by a day be healed by night? Jaumal of Theretical Bidogy 141: 259 280.

Pierre, M., Raphael Matre, P., Morillon, R., Burrieu, F., Gretchen, B.N., Nobel, 


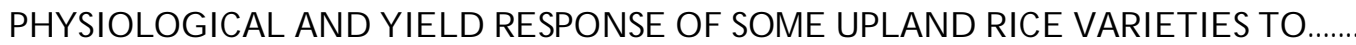

P.S., Chrispeels, M. 2002. Plasma membrane Aquaporin play a significant role during recovery of water deficit. Plant Physidogy 130: 2101 - 2110.

Reddy, A.R., Chaitanya, K.V., Vivekanandan, M. 2004. D rought-induced responses of photosynthesis and anti-oxidant metabolism in higher plants. Jaumal of Plant Physidogy 161: 1189 - 1202.

Sperry, J.S., Holbrook, N.M., Zimmermann, M.H., Tyree, M.T. 1987. Spring filling of xylem vessels in wild grapevine. Plant Physidogy 83: 414 - 417.

Spollen, W.G., Sharp, R.E. 1991. Spatial distribution of turgor and root growth at low water potential. Plant Physidogy 98: 438 443.

Taiz, L., Zeiger, E. 2003. Plant Physidogy. 3. Edited by Steffen et al. New Delhi: Panima Publishing Corporation.

Thompson, D.S., Davies, W.J., Ho, L.C. 1998. Regulation of tomato fruit growth by epidermal cell wall enzymes. Plant, Cell and Envirament 21: 589 - 599.

Tyree, M.T., Fiscus, E.L., Wullschleger, S.D., Dixon, M.A. 1986. Detection of xylem cavitation in corn (Zea mays) under field conditions. Plant Physidogy 82: 597 599.

Volker, S., Lafitte, R.H., Sperry, J.S. 2003. Hydraulic properties of Rice and response of gas exchange to water stress. Plant Physidogy 132: 1698 - 1706.

Zinolabedin, T.S., Hemmatollah, P., Seyed, A.M., Modarres, S., Hamidreza, B. 2008. Study of water stress effects in different growth stages on yield and yield com- ponents of different rice (Oryza sativa L.) cultivars. Pakistan Jaumal of Bidogical Saiences 11:1303-1309.

Auxin-regulated genes encoding cell wallmodyfying proteins are expressed during early tomato fruit growth. Plant Physidogy 122: 527 - 534.

Chang, T.T., Bardenas, E.A., Amulfo, C., Rosario, D. 1965. The morphology and varietal characteristics of the rice plant. Tehnical Bullein 4 Deember, the International Rice Research Institute, Los Banos, Laguna, the Philippines.

Cheves, M.M., Maroco, J.P., Pereira, J.S. 2003. Understanding plant response to drought-from genes to the whole plant. Func tional Plant Bidogy30: 239 - 264.

Cochard, H., Ewers, F.W., Tyree, M.T. 1994. Water relations of a tropical vine-like bamboo (Rhipidocladum racemiflorum): root pressures, vulnerability to cavitation and seasonal changes in embolism. Jaumal of Expeimental Bdany 45: 1085 - 1089.

Galle, A., Florez-Sarasa, T., Tomas, M., Pou, A., Medraino, H., Ribas-Carbo, M., Flexas, J. 2009. The role of mesophyll conductance during water stress and recovery in tobacco (Nicotiana sylvestris): Acclimation or limitation. Jaumal of Expeimental Bdany 60 (8): 2379 - 2390.

Gomez, K.A. 1972. Tehniques for fidd expeiments with rice International Rice Research Institute, Los Banos, Philppines.

Hu., L., Wang, Z., Huang, B. 2012. Growth and Physiological recovery of kentucky Bluegrass from drought stress as affected by a synthetic cytokinin 6- 
Benzylaminopurine. Crop Säene 52: 2331 2340.

Innes, P., Blackwell, R.D. 1983. Some effects of leaf posture on the yield and water economy of wheat. Jaumal of Agiailtural Säme101:367-376.

Jones, M.P., Dingkuhn, M., Aluko, G.K., Mande, S. 1997a. Interspecific Oryza sativa 0 . glabberima steud progenies in ipland ricr improvement. Euphytica 92: 237 246.

Jones, M.P., Mande, S., Aluko, K. 1997b. Diversity and potantial of Oryza glabberima Steud. in lowland rice breeding. Breeding Saene47: 395 - 398.

Lechner, L., Gustavo, A., Pereyra-Irujo., Grainer, S., Aguimezabal, L.A.N. 2008. Rewatering plants after a long water deficit treatment reveals that leaf epidermal cells retain their ability to expand after the leaf has apparently reached its final size. Annals of Bdany 101: 1007 - 1025.

Lockhart, J.A. 1965. Analysis of a reversible plant cell elongation. Jamal of Theretical Bidogy,: 264 - 275.

Lu, Y., Deng, X., Kwak, S. 2010. Over expression of $\mathrm{CuZn}$ Superoxide dismutase (CuZnSOD) and Ascorbate Peroxidase (APX) in transgenic sweet potato enhances tolerance and recovery from drought stress. African Jaumal of Bidtechndogy. 9(46): 8378 8391.

MacAdam, J.N., Nelson, C.J., Sharp, R.E. 1992. Peroxidase activity in the leaf elongation zone of tall fescue:I. Spatial distribution of ionically bound peroxidase activity in genotype differing in length of elongation zone. Plant Physidogy 99: 872 873.

Miller, D.M. 1985. Studies of root function in Zea mays: III. Xylem sap composition at maximum root pressure provides evidence of active transport into the xylem and a measurement of the reflection coefficient of the root. Plant Physidooy 13: 383 - 388.

Monneveux, P., Reynolds, M.P., Gonzalez-Santoyo, H., Pena, R.J., Mayr, L., Zapata, F. 2004. Relationship between grain yield, leaf morphology, carbon isotope discrimination and ash content in irrigated wheat. Jamal of Agrommy and Crop Saience 190:395-401.

Oikeh, S.O., Nwilene, F.E., Agunbiade, T.A., Oladimeji, 0., Ajayi, 0., Semon, M., T sunematsu, H., Samejima, H. 2008. Growing upland rice: A production handbook Africa Rice Centre. AfricaRice, Cotonou, Benin, 44pp.

Picard, W.F. 1989. How might a tracheary element is embolized by a day be healed by night? Jarmal of Theretical Bidogy 141: 259 280.

Pierre, M., Raphael Matre, P., Morillon, R., Burrieu, F., Gretchen, B.N., Nobel, P.S., Chrispeels, M. 2002. Plasma membrane Aquaporin play a significant role during recovery of water deficit. Plant Physidogy 130: $2101-2110$.

Reddy, A.R., Chaitanya, K.V., Vivekanandan, M. 2004. D rought-induced responses of photosynthesis and anti-oxidant metabolism in higher plants. Jaumal of Plant Physidogy 161: 1189 - 1202.

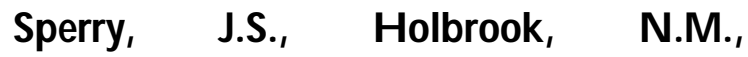


Zimmermann, M.H., Tyree, M.T. 1987. 599.

Spring filling of xylem vessels in wild grapevine. Plant Physidogy 83: 414 - 417.

Volker, S., Lafitte, R.H., Sperry, J.S. 2003.

Hydraulic properties of Rice and response of

Spollen, W.G., Sharp, R.E. 1991. Spatial distribution of turgor and root growth at low water potential. Plant Physidogy 98: 438 443. gas exchange to water stress. Plant Physidogy 132: $1698-1706$.

Taiz, L., Zeiger, E. 2003. Plant Physidogy. 3.

Zinolabedin, T.S., Hemmatollah, P., Edited by Steffen et al. New D elhi: Panima Publishing Corporation.

Thompson, D.S., Davies, W.J., Ho, L.C. 1998. Regulation of tomato fruit growth by epidermal cell wall enzymes. Plant, Cdl and EnMronment 21: 589 - 599.

Tyree, M.T., Fiscus, E.L., Wullschleger, S.D., Dixon, M.A. 1986. Detection of xylem cavitation in corn (Zea mays) under field conditions. Plant Physidogy 82: 597 -

(Manuscript reecived 23rdJuly, 2013; accepted 27th Febnary, 2015) 